\title{
Use of Starch Granules Enriched with Carvacrol for the Lesser Mealworm, Alphitobius diaperinus Control in Chicken House: Effects on Insects and Poultry
}

\author{
Maryla Szczepanik ${ }^{1}$, Aneta Raszkowska-Kaczor ${ }^{2}$, Daria Olkiewicz ${ }^{3}$, Dagmara Bajer ${ }^{4}$ and Krzysztof Bajer ${ }^{2}$ \\ ${ }^{1}$ Nicolaus Copernicus University, Faculty of Biology and Environment Protection, \\ Department of Invertebrate Zoology and Parasitology, Lwowska 1, 87-100 Toruń, Poland \\ ${ }^{2}$ Łukasiewicz Research Network - Institute for Engineering of Polymer Materials and Dyes, \\ M. Skłodowskiej-Curie 55, 87-100 Torun, Poland \\ ${ }^{3}$ Nicolaus Copernicus University, Faculty of Biology and Environment Protection, \\ Department of Environmental Microbiology and Biotechnology, Lwowska 1, 87-100 Toruń, Poland \\ ${ }^{4}$ Nicolaus Copernicus University, Faculty of Chemistry, Gagarina 7, 87-100 Toruń, Poland
}

\begin{abstract}
The aim of this study was to investigate the effect of starch granules enriched with carvacrol and mixed with straw pellets (as poultry litter) on the mortality of larvae and adults of the lesser mealworm, Alphitobius diaperinus Panzer, a cosmopolitan pest inhabiting chicken houses in vast numbers worldwide. Additionally, the effect of starch granules on the growth parameters and survival of broiler chickens exposed to treated litter was examined. In this study, granules containing 3,5, and $10 \%$ carvacrol was used. In a simulated chicken house bioassay, this material was mixed with pellets in three different proportions: 30/70\%, 40/60\%, and 50/50\% (granules/pellets, respectively). On this medium, young larvae (approximately 10 days old), older larvae (last stage before pupa), and unsexed 7-10 days old adults of the lesser mealworm, with access to food, were colonized. Experiments were performed at $29^{\circ} \mathrm{C}$ in the dark. The study shows that poultry litter with the addition of starch granules enriched with $10 \%$ of carvacrol in the proportion of 40:60\% (granules:pellets) appears to be the optimal medium applicable to broiler houses for $\mathrm{A}$. diaperinus control. In this environment, all larvae and adults died within 3-4 days and the overall development of the experimental chickens was similar to that of the control. However, the feed conversion rate was slightly higher in the treated group (1.72) than in the control group (1.56). The average final body weight in the treated group was $100 \mathrm{~g}$ lower than that in the control group (the differences were not statistically significant).
\end{abstract}

Key words: Alphitobius diaperinus, carvacrol, lesser mealworm, starch granules

J. Poult. Sci., 57: 168-174, 2020

\section{Introduction}

Eliminating insects inhabiting chicken houses is still an unresolved problem in the poultry industry worldwide. A common insect in poultry farms is the lesser mealworm, Alphitobius diaperinus Panzer. This insect, because of its tropical origin, has fully adapted to conditions prevailing in poultry houses. It appears in large numbers in poultry litter

Received: May 27, 2019, Accepted: August 2, 2019

Released Online Advance Publication: October 25, 2019

Correspondence: Maryla Szczepanik, Associate Professor, Nicolaus Copernicus University, Faculty of Biology and Environment Protection, Department of Invertebrate Zoology, Lwowska 1, 87-100 Torun, Poland. (E-mail: mszczep@umk.pl)

The Journal of Poultry Science is an Open Access journal distributed under the Creative Commons Attribution-NonCommercial-ShareAlike 4.0 International License. To view the details of this license, please visit (https:// creativecommons.org/licenses/by-nc-sa/4.0/). and manure, especially under feeders and drinking troughs. This pest feeds primarily on spilled poultry feed or cracked eggs but eats sick and weakened or dead chickens as well (Axtell and Arends, 1990; Salin et al., 2000). It is well known that this pest is a source and vector of several pathogens such as bacteria, viruses, fungi, protozoa, and platyhelminthes parasites that cause serious poultry and human diseases (Watson et al., 2000; Hazeleger et al., 2008; Roche et al., 2009). In addition, A. diaperinus destroys thermal insulation systems in poultry houses when mature larvae emigrate to search for isolated pupation sites (Vaughan et al., 1984). Such a damage causes temperature drop inside buildings. Thus, its presence in poultry houses creates serious sanitary and economic problems for poultry farmers. The basic method for controlling the pest is by applying chemical insecticides such as pyrethroids, organophosphorus compounds, macrocyclic lactones, and benzylurea compounds, at the end of the poultry cycle. However, these methods are 
ineffective and do not provide long-term protection against the pest. Continuous usage of these insecticides results in the selection of resistant pest population and increased levels of the chemicals used in the environment. An increasing number of publications have described the resistance of pest to these compounds in several countries (Tomberlin et al., 2008; Chernaki-Leffer et al., 2011; Hickmann et al., 2018). Thus, owing to environmental pollution caused by the excessive use and misuse of agrochemicals and the requirements of health food from consumers, alternative methods must be sought. This problem may solved by introducing proecological factors into chicken houses to ensure longterm protection against the pest as well as guaranteeing poultry safety. This can be achieved by using essential oils or their main components, especially terpenes. The toxic and behavioral effects of these natural products on the lesser mealworm has been well documented in literature (Szczepanik and Szumny, 2011; Prado et al., 2013; Szołyga et al., 2014; Testa et al., 2018). The results of these studies show that essential oils or their components obtained from various plant species can be used to control $A$. diaperinus. The methods of their application in poultry houses can differ; they can be used as a feed additive in poultry nutrition, dietary antibiotic replacer, botanical insecticide, or additive to broiler litter material (Hippenstiel et al., 2011). An appropriate polymer carrier containing components of essential oils can be easily mixed in a suitable proportion with the litter and remain in the broiler house throughout the entire poultry cycle. The role of such a carrier may be fulfilled using starch.

Starch consists of two fractions: amylose $\{(\mathrm{C} 6 \mathrm{H} 10 \mathrm{O} 5) \mathrm{n}$ where $n=5000\}$ and amylopectin $\{(\mathrm{C} 6 \mathrm{H} 10 \mathrm{O} 5) n$, where $n=$ $50000\}$, in $20-25 \%$ and $75-80 \%$, respectively (Raquez et al., 2008). Pure starch is a white, semi-crystalline substance free of smell and taste (Kapuśniak et al., 2011; Bajer et al., 2012). Its melting point range is $220-240^{\circ} \mathrm{C}$ and its glass transition temperature is $230^{\circ} \mathrm{C}$, higher than its decomposition point at $220^{\circ} \mathrm{C}$. Therefore, processing starch in its pure form is difficult; starch must be subjected to plastification to lower its glass transition point, thus breaking the hydrogen bonds and partly decomposing the starch (Poutanen and Forssel, 1996). Using an increased amount of plasticizer softens all types of starch and lowers the glass transition point (Yu et al., 1998; Mościcki et al., 2009; Bajer et al., 2011). Starch of $10 \%$ humidity and glycerol content $20-$ $35 \%$ shows a glass transition point $(\mathrm{Tg})$ of up to $83-71^{\circ} \mathrm{C}$ (Yu et al., 1998). Van Soest and Knooren (1997) stated that starch of $11 \%$ humidity and glycerol content $26 \%$ shows $\mathrm{Tg}$ $=40^{\circ} \mathrm{C}$. The glass transition point of starch materials of considerable humidity and glycerol content is lower than $20^{\circ} \mathrm{C}$ (Mitrus, 2009).

Glycerin, sorbitol, water, ethylene glycol, urea, formamide, and acetamide are among the most commonly used plasticizers (Poutanen and Forssel, 1996; Park et al., 2005; Spychaj et al., 2006; Galdeano et al., 2009; Bajer et al., 2011). Water as a starch modifier limits the upper processing temperature by extruction blowing molding because of water vapor emission leading to porosity of the material (Thunwall et al., 2008). Plasticizer causes an interaction between starch macromolecules that increases the elongation at break as well as impact strength, thus lowering the tensile strength (Rychter et al., 2016).

Our previous studies have shown that carvacrol significantly impaired the growth and development of $A$. diaperinus larvae and is toxic to this pest (Szczepanik et al., 2012; Szczepanik et al., 2018). Therefore, we hypothesize that this monoterpene phenol may be useful for reducing or eliminating insect infestations in poultry houses without toxicity to birds exposed to treated litter. The aim of this study was to investigate the effect of starch granules enriched with carvacrol and mixed with straw pellets as poultry litter on the mortality of larvae and adults of the lesser mealworm. Furthermore, the effect of these granules on the growth parameters and survival of broiler chickens exposed to treated litter was examined.

\section{Materials and Methods}

\section{Chemicals}

Native potato starch (Wielkopolska Potato Industry S. A. Luboń, Poland) was used in the study. The plasticizer used was propane-1,2,3-triol (Chempur, Piekary Śląskie, Poland) of density $1,26 \mathrm{~g} / \mathrm{cm}^{3}$. Calcium carbonate (Chemical Processing Plant and Mineral Resources "Piotrowice," Poland) as the filler and carvacrol (Sigma Aldrich, Poznań, Poland) of density $0,976 \mathrm{~g} / \mathrm{cm}^{3}$ as a compound with insecticidal activity were used.

\section{Starch Granules Enriched with Carvacrol Preparation}

The biodegradable material with insecticidal properties was obtained as follows: $2 \%$ each of potato starch powder, propane-1,2,3-triol (28\%), and calcium carbonate and carvacrol in the respective proportions were introduced into a planetary mixer. All ingredients were mixed using a stirrer at 60-120 rpm for $9 \pm 2 \mathrm{~min}$ (Bajer et al., 2017).

The pellets were extruded using a single-screw extruder, Plasti-Corder PLV 151 (Brabender GmbH \& Co., Germany). The screw had a working length 25D (outer diameter 19.5 $\mathrm{mm}$ ) and a compression ratio 3:1. The temperature profile along the cylinder was as follows: $70,80,90$, and $95^{\circ} \mathrm{C}$ (die head). The screw rotation speed was $100 \mathrm{rpm}$. The obtained starch composite, in pellets form with average diameter 3-4 $\mathrm{mm}$, is safe for the environment, as verified by the method described earlier (Mitrus and Mościcki, 2009).

\section{Bioassays}

In this study, larvae and adults from a laboratory colony of the lesser mealworm were used. The insects were originally collected from a naturally infested poultry litter in a commercial chicken farm near Torun $\left(53^{\circ} 01^{\prime} \mathrm{N}, 18^{\circ} 37^{\prime} \mathrm{E}\right.$, Poland). The insects were stored in glass containers on a diet consisting of 1 part oat flakes, 1 part wheat bran, 0.01 parts brewers' yeast and apple halves to maintain the moisture levels at $60 \pm 5 \%$ relative humidity. Cotton was placed inside containers to provide a good pupation environment. The colony was kept in a rearing chamber at $+29^{\circ} \mathrm{C}$ in the dark. 


\section{Toxicity of Starch Granules Modified with Carvacrol Against A. diaperinus}

The toxicity of the granules was evaluated in a laboratory. In these studies, granules containing 3 and $5 \%$ carvacrol were used. The granules $(5 \mathrm{~g})$ were placed in $100-\mathrm{mL}$ plastic containers lined with moistened filter paper. Each container was filled with 10 young larvae (approximately 10 days old), 10 older larvae (last stage before pupa), and 10 unsexed, 7-10 days old adults (total insects $=30$ ). In the control samples, pure starch granules were used. During the entire experimental period, water in filter paper and oat flakes as food were available. All containers were placed in incubators at $29^{\circ} \mathrm{C}$ and $60 \pm 5 \%$ r.h. in the dark. The mortality of the insects was assessed daily and corrected by Abbott's formula (Abbott, 1925). Four replicates were performed for each treatment.

\section{Simulated Chicken House Bioassay}

The next stage of our research was the assessment of granule toxicity in conditions similar to the natural. In a chicken house, the granules can be mixed with poultry litter (pellets) in suitable proportions and placed over the entire area of the house. The research on the percentage composition and toxicity of such a mixture was performed in glass containers $(20 \mathrm{~cm} \times 20 \mathrm{~cm} \times 15 \mathrm{~cm}$ length/width/depth) lined with moistened filter paper and filled with a mixture of granules and pellets. Granules containing 3, 5 and $10 \%$ of carvacrol was used. Granules with the addition $3 \%$ of carvacrol were used in a 50/50\% ratio with pellets. Granules containing $5 \%$ of carvacrol were mixed with pellets in two proportions: $40 / 60 \%$ (granules/pellets, respectively) and 50/ $50 \%$. Granules with a higher dose $(10 \%)$ of carvacrol were used in three variants: $30 / 70 ; 40 / 60$ and $50 / 50 \%$ (granules/ pellets, respectively). On this medium, 10 young larvae (approximately 10 days old), 10 older larvae (last stage before pupa) and 10 unsexed, 7-10 days old adults were colonized. All had access to food. The experiments were performed at $+29^{\circ} \mathrm{C}$ in the dark in 4-replicates for each treatment. Insect mortality was recorded each day and corrected by Abbott's formula (Abbott, 1925). In the control samples pure starch granules mixed with pellets in appropriate proportions was used.

\section{Effect of Granules on Chicken Growth Performance}

This study was performed at the Faculty of Animal Breeding and Biology at the University of Technology and Life Science in Bydgoszcz (Poland) as contracted research. It was performed in accordance with the Polish law concerning animal experiments. One-day-old male broiler chickens (Ross 308) were purchased from a local hatchery. They were placed in two $2.5 \mathrm{~m}^{2}$ boxes and there were 33 broilers in each box. Continuous lighting was provided throughout the experimental period. The ambient temperature was decreased gradually from $32^{\circ} \mathrm{C}$ on day 0 to $25^{\circ} \mathrm{C}$ on day 21 and subsequently kept constant. All chickens underwent veterinary evaluation. The birds in the control group were kept on a commercial pellet bedding ( $15 \mathrm{~kg}$ in box); the treatment group was cultured on pellet litter mixed with granules containing $10 \%$ carvacrol ( $9 \mathrm{~kg}$ pellets and $6 \mathrm{~kg}$ granules).
This carvacrol dose was based on the results presented in Table 2. During the study, the birds were reared in accordance with the instructions in the technical manual for rearing broiler chickens Ross 308 (www.aviagen.com). The chickens were fed ad libitum with commercial, isocaloric, and isotonic, full-compound feed mixtures: starter from 0 to 10 days; grower I from 11 to 21 days; grower II from 22 to 35 days; finisher from 36 to 42 days of growth period. They had unlimited access to water and remained under a veterinarian's care.

During the study, the following performance parameters of the experimental chickens were evaluated: body weight gain (individual body weights were measured weekly), feed intake, feed conversion, and mortality. The feed intake from 0-21 days and 0-42 days for both experimental groups was calculated by dividing the amount of feed consumed by the numbers of days and chickens. The obtained results were used to calculate the feed conversion ratio. The daily feed and water intake on the last day of the experiment was calculated by dividing the amount of feed and water consumed by the number of birds.

\section{Statistical Analysis}

Data from the toxicity of starch granules enriched with carvacrol against $A$. diaperinus were statistically analyzed using a generalized linear mixed model with binomial distribution and logit link function (SPSS, IBM 25.0). Replicates were included as a random factor. The results were considered significant when $P<0.05$. The student's t-test (Microsoft Office 2010, Excel) was used to compare the body weights of the experimental broilers.

\section{Results and Discussion}

The high toxicity of the granules against larvae and adults of A. diaperinus was indicated in the study. All insects, after being in contact with granules containing 5\% carvacrol, died within $24 \mathrm{~h}$. With the lower content (3\%) of carvacrol in the granules, the rate of insect dieback was lower. After $24 \mathrm{~h}$, $22.5 \%$ of younger larvae and only $10 \%$ of older larvae and adults were killed. The insect mortality increased over the next few days and became extremely high around the fifth or sixth day. For the larvae, mortality was approximately $90 \%$ and all adults died within four days after administration (Table 1).

The survival rate of the insects colonized on litter with the addition of granules containing carvacrol depended on the concentration of terpene in the granules and the amount of granules used in relation to the pellets. The litter containing granules with the lowest carvacrol content, $3 \%$, had a limited effect. This environment was toxic only for the larvae, especially for younger ones; they died within six days. By contrast, the survival rate of the adults was high; during one week, only $20 \%$ of the insects died (Table 2). Poultry litter mixed with granules containing $5 \%$ carvacrol was toxic only to larvae, especially in equal proportions; therefore, those granules were not highly effective. The total mortality of adults in both variants was at a similarly low level. This creates the risk of a relatively rapid restoration of the pest 
Table 1. Toxicity of starch granules containing $3 \%$ carvacrol against A. diaperinus

\begin{tabular}{|c|c|c|c|c|c|c|c|}
\hline \multirow{3}{*}{$\begin{array}{l}\text { Development } \\
\text { stage }\end{array}$} & \multicolumn{7}{|c|}{ Mortality $(\%) \pm \mathrm{SE}^{1}$} \\
\hline & \multicolumn{7}{|c|}{ Days after treatment } \\
\hline & 1 & 2 & 3 & 4 & 5 & 6 & 7 \\
\hline Younger larvae & $22.5 \pm 4.7$ & $40.0 \pm 5.8$ & $60.0 \pm 8.8$ & $83.0 \pm 2.9$ & $93.0 \pm 3.3$ & $93.0 \pm 3.3$ & 100 \\
\hline Older larvae & $10.0 \pm 4.1$ & $30.0 \pm 4.1$ & $53.3 \pm 8.8$ & $83.0 \pm 5.8$ & $90.0 \pm 5.0$ & $90.0 \pm 5.0$ & 100 \\
\hline Adults & $10.0 \pm 2.9$ & $30.0 \pm 5.8$ & $60.0 \pm 4.1$ & 100 & & & \\
\hline F & 1.59 & 0.6 & 0.137 & 1.079 & 0.759 & 0.759 & \\
\hline $\mathrm{df}$ & 2.9 & 2.9 & 2.9 & 2.6 & 2.6 & 2.6 & \\
\hline $\mathrm{p}$ & 0.257 & 0.572 & 0.874 & 0.398 & 0.508 & 0.508 & \\
\hline
\end{tabular}

${ }^{1}$ Values are means of four replicates, each set up with 10 insects $(n=40)$. Means within each column are not significantly different.

Table 2. Toxicity of poultry litter mixed with starch granules enriched with carvacrol against $A$. diaperinus

\begin{tabular}{|c|c|c|c|c|c|c|c|c|}
\hline \multirow{4}{*}{$\begin{array}{l}\text { Carvacrol- } \\
\text { dose } \%\end{array}$} & \multirow{4}{*}{$\begin{array}{c}\text { Granulate: } \\
\text { pellets } \\
\%\end{array}$} & \multicolumn{7}{|c|}{ Mortality $(\%) \pm \mathrm{SE}^{1}$} \\
\hline & & \multicolumn{7}{|c|}{ Days after treatment } \\
\hline & & 1 & 2 & 3 & 4 & 5 & 6 & 7 \\
\hline & & \multicolumn{7}{|c|}{ Younger larvae } \\
\hline 3.0 & $50: 50$ & 0 & $20.0 \pm 4.1^{\mathrm{a}}$ & $37.5 \pm 7.5^{\mathrm{b}}$ & $56.7 \pm 3.3^{\mathrm{a}}$ & $60.0 \pm 5.8^{\mathrm{a}}$ & 100 & \\
\hline \multirow[t]{2}{*}{5.0} & $40: 60$ & 0 & $10.0 \pm 4.1^{\mathrm{a}}$ & $10.0 \pm 4.5^{\mathrm{a}}$ & $60.0 \pm 5.7^{\mathrm{a}}$ & $76.6 \pm 8.3^{\mathrm{a}}$ & 100 & \\
\hline & $50: 50$ & 0 & $25.0 \pm 2.9^{\mathrm{ab}}$ & $67.5 \pm 12 b^{c}$ & $100^{\mathrm{b}}$ & & & \\
\hline \multirow[t]{3}{*}{10.0} & $30: 70$ & $12.5 \pm 6.9^{\mathrm{a}}$ & $45.0 \pm 6.4^{\mathrm{b}}$ & $80.0 \pm 5.7^{\mathrm{c}}$ & $87.5 \pm 6.2^{\mathrm{c}}$ & $97.5 \pm 2.5^{\mathrm{b}}$ & 100 & \\
\hline & $40: 60$ & $20.0 \pm 4.1^{\mathrm{a}}$ & $80.0 \pm 7.1^{\mathrm{c}}$ & $100^{\mathrm{d}}$ & & & & \\
\hline & $50: 50$ & $10.0 \pm 4.1^{\mathrm{a}}$ & $100^{\mathrm{d}}$ & & & & & \\
\hline $\mathrm{F}$ & & 0.846 & 9.84 & 6.94 & 11.44 & 4.53 & & \\
\hline df & & 2.9 & 5.18 & 4.15 & 3.12 & 2.9 & & \\
\hline $\mathrm{p}$ & & 0.46 & $<0.001$ & 0.002 & 0.001 & 0.043 & & \\
\hline \multicolumn{9}{|c|}{ Older larvae } \\
\hline 3.0 & $50: 50$ & 0 & 0 & $10.0 \pm 0^{\mathrm{a}}$ & $30.0 \pm 5.8^{\mathrm{a}}$ & $32.5 \pm 2.5^{\mathrm{a}}$ & $64.0 \pm 6.7^{\mathrm{b}}$ & $75.5 \pm 5.0^{\mathrm{a}}$ \\
\hline \multirow{2}{*}{5.0} & $40: 60$ & 0 & 0 & 0 & $65.0 \pm 6.4^{\mathrm{b}}$ & $86.7 \pm 3.3^{\mathrm{b}}$ & $100^{\mathrm{c}}$ & $100^{\mathrm{b}}$ \\
\hline & $50: 50$ & 0 & $15.0 \pm 2.9^{\mathrm{a}}$ & $47.5 \pm 6.1^{\mathrm{b}}$ & $67.5 \pm 3.3^{\mathrm{b}}$ & $93.3 \pm 3.3^{\mathrm{b}}$ & $100^{\mathrm{c}}$ & $100^{\mathrm{b}}$ \\
\hline \multirow[t]{3}{*}{10.0} & $30: 70$ & 0 & 0 & $7.5 \pm 4.8^{\mathrm{a}}$ & $15.0 \pm 6.3^{\mathrm{a}}$ & $21.3 \pm 4.3^{\mathrm{a}}$ & $32.5 \pm 4.8^{\mathrm{a}}$ & $57.5 \pm 4.8^{\mathrm{a}}$ \\
\hline & $40: 60$ & $10.0 \pm 0.0^{\mathrm{a}}$ & $20.0 \pm 4.1^{\mathrm{a}}$ & $57.5 \pm 4.8^{\mathrm{bc}}$ & $100^{\mathrm{c}}$ & & & \\
\hline & $50: 50$ & $10.0 \pm 2.1^{\mathrm{a}}$ & $32.5 \pm 6.3^{\mathrm{a}}$ & $72.5 \pm 4.8^{\mathrm{c}}$ & $100^{\mathrm{c}}$ & & & \\
\hline $\mathrm{F}$ & & 1.14 & 1.80 & 10.65 & 8.37 & 17.01 & 6.83 & 3.98 \\
\hline $\mathrm{df}$ & & 2.9 & 2.9 & 4.15 & 5.18 & 3.12 & 3.12 & 3.12 \\
\hline $\mathrm{p}$ & & 0.36 & 0.22 & $<0.001$ & $<0.001$ & $<0.001$ & 0.006 & 0.035 \\
\hline \multicolumn{9}{|c|}{ Adults } \\
\hline 3.0 & $50: 50$ & 0 & 0 & 0 & 0 & 0 & $10 \pm 0.0^{\mathrm{a}}$ & $20 \pm 5.8^{\mathrm{a}}$ \\
\hline \multirow[t]{2}{*}{5.0} & $40: 60$ & $10.0 \pm 3.9$ & $10.0 \pm 4.1^{\mathrm{a}}$ & $10.0 \pm 4.1^{\mathrm{a}}$ & $10.0 \pm 4.1^{\mathrm{a}}$ & $16.7 \pm 7.6^{\mathrm{a}}$ & $16.7 \pm 8.8^{\mathrm{a}}$ & $16.7 \pm 8.8^{\mathrm{a}}$ \\
\hline & $50: 50$ & 0 & 0 & $5.0 \pm 2.9^{\mathrm{a}}$ & $17.5 \pm 6.3^{\mathrm{a}}$ & $23.3 \pm 12.6^{\mathrm{a}}$ & $23.3 \pm 12.1^{\mathrm{a}}$ & $23.3 \pm 12.1^{\mathrm{a}}$ \\
\hline \multirow[t]{3}{*}{10.0} & $30: 70$ & 0 & 0 & 0 & $7.5 \pm 2.5^{\mathrm{a}}$ & $7.5 \pm 2.5^{\mathrm{a}}$ & $16.2 \pm 2.4^{\mathrm{a}}$ & $22.5 \pm 12.1^{\mathrm{a}}$ \\
\hline & $40: 60$ & 0 & $27.5 \pm 6.3^{\mathrm{ab}}$ & $100^{\mathrm{b}}$ & $100^{\mathrm{b}}$ & & & \\
\hline & $50: 50$ & 0 & $47,5 \pm 6.3^{\mathrm{b}}$ & $100^{\mathrm{b}}$ & $100^{\mathrm{b}}$ & & & \\
\hline $\mathrm{F}$ & & & 6.04 & 8.59 & 6.24 & 0.69 & 0.265 & 0.16 \\
\hline df & & & 2.9 & 3.12 & 4.15 & 2.7 & 2.7 & 3.1 \\
\hline $\mathrm{p}$ & & & 0.022 & 0.003 & 0.004 & 0.534 & 0.775 & 0.921 \\
\hline
\end{tabular}

${ }^{1}$ Values are means of four replicates, each set up with 10 insects $(n=40)$. Means within a column for each stage with different superscripts are significantly different.

population. The introduction of a smaller amount (30\%) of granules to the litter, but with a higher content of carvacrol $(10 \%)$ was effective only against younger larvae. After three days, only $20 \%$ of these larvae remained alive and during one week, all larvae died. However, this variant was not effective against older larvae and adults. The mortality of 
older larvae after one week was only above $50 \%$; for adults, it was approximately $20 \%$ (Table 2 ). Increasing the amount of these granules in the litter to $40 \%$ resulted in a significant increase in toxicity of the substrate for all tested developmental stages of the pest. Three days after treatment, all younger larvae and adults died; mortality among the older larvae was $57.5 \%$. After the next day, mortality among the older larvae increased to $100 \%$. A comparison of the results shows that adding 40 and $50 \%$ of the granules into the litter, i.e., an addition exceeding $10 \%$, does not increase the mortality among insects significantly. From a practical and economic perspective, poultry litter with the addition of starch granules with $10 \%$ carvacrol in ratio $40: 60 \%$ (granules:pellets) appears to be the optimal medium applicable to broiler houses for $A$. diaperinus control.

Higher doses of essential oils as a pest control agent are required in broiler houses compared with synthetic insecticides. The low doses, at levels of $1-3 \%$, used in natural conditions had no effect, especially against later developmental stages. This has been confirmed by other researchers. For example, Cunila angustifolia essential oil showed an efficacy of $100 \%$ for both larvae and adults when it was used at concentrations of 5 and 10\% (Prado et al., 2013). Similarly, 5\% Cinnamomum zeylanicum essential oil used with pine shavings reduced infestation by Alphitobius diaperinus in poultry litter (Testa et al., 2018). However, after applying a $5 \%$ dose, a second application of the oil was required in the middle of the chicken rearing cycle. It can be assumed that the use of granules containing 5\% carvacrol in two applications can be equally effective. Meanwhile, a higher dose of carvacrol accelerates mortality at all life stages of the pest and prevents re-infestation.

The observed effect of carvacrol on the growth performance of male ROSS 308 chickens is non-significant. The growth, health, and survival recorded during the rearing of the broiler chickens depended primarily on the quality of the inserted hatchlings. The starting average body weight of the hatchlings was similar to the value of the indicator $(42 \mathrm{~g})$ contained in the "ROSS 308 Broiler Performance Objectives" (2014) (www.aviagen.com) and ranged from $42.9 \mathrm{~g}$ in the control to $42.7 \mathrm{~g}$ in the treatment group. During the first 3 weeks of chicken life, a high rate of body weight gain in both groups was observed (Table 3). The average body weight of these broilers was even higher than the standard of $959 \mathrm{~g}$. In this period, only one broiler chicken from the control group died. From the third to the fifth week, the body weight of broiler chickens exposed to treated litter was higher compared to that of the control, but without significant statistical differences (Table 3 ). The high body weight gain of all chickens recorded between day 21 and 42 of rearing increased the density of chickens in the experimental boxes from 33 to $40 \mathrm{~kg} / \mathrm{m}^{2}$. This could be a reason contributing to the increase in broiler chicken mortality. During this period, six broiler chickens in the carvacrol group died, while only three died in the control group (Table 3). Carcasses of the dead birds were assessed by veterinary examination. Based on anatomopathological changes observed through bacteriological and parasitological tests of the intestinal mucosa, it was found that the cause of broiler chicken death was advanced colibacillosis, with symptoms of inflammation in the upper and lower respiratory tracts. Colibacillosis can be caused by poor environmental conditions (highly dusty chicken house, presence of ammonia in the environment, and overcrowding). However, considering the intense odor of carvacrol with a strong irritating effect emitted from litter, lack of dust, imperceptible odor of ammonia in the experimental room, and exceedance in bird body weight, determining the direct cause of colibacillosis of the respiratory tract of the chickens is difficult. However, it appears that the strong smell of carvacrol as the cause of broiler chicken death can be ruled out. In the first three weeks when the odor emission was the strongest, death was not observed among the carvacrol-treated birds. The observed increase in bird mortality in this period was likely the result of the onset of sudden cardiac death among experimental chickens that had an intense initial rate of weight gain and subsequently achieved a large, final body weight.

The rate of feed utilization by the broiler chickens is shown in Table 4. From 0 to 21 days, the feed conversion ratio was almost the same for both groups. However, when determined for 42 days of poultry farming, the ratio increased from 1.54 (control) to 1.72 for the treated group. Meanwhile, the daily feed intake on the last day of rearing was almost the same for both groups. Thus, the effect of treated litter on feed utilization by chickens requires further detailed research.

Table 3. Effect of treated litter on growth and survival rate of broiler chickens

\begin{tabular}{cccccccc}
\hline \hline \multirow{2}{*}{ Broiler group } & \multicolumn{7}{c}{ Body weight $(\mathrm{g}) \pm \mathrm{SD}^{1}$} \\
\cline { 2 - 7 } & \multicolumn{7}{c}{ Days after treatment } \\
\cline { 2 - 7 } & Start & 7 & 14 & 21 & 28 & 35 \\
\hline \multirow{2}{*}{ Control } & $42.9 \pm 2.8$ & $217.5 \pm 17.4$ & $596.6 \pm 43.3$ & $1066.2 \pm 84.6$ & $1587.1 \pm 155.3$ & $2274.6 \pm 155.3$ & $3002.9 \pm 344.7$ \\
& $n=33$ & $n=33$ & $n=32$ & $n=32$ & $n=32$ & $n=32$ & $n=30$ \\
Treatments & $42.7 \pm 3.4$ & $216.7 \pm 13.4$ & $586.8 \pm 44.0$ & $1094.7 \pm 101.0$ & $1613.9 \pm 201.1$ & $2294.4 \pm 313.5$ & $2910.3 \pm 330.8$ \\
P & $n=33$ & $n=33$ & $n=33$ & $n=33$ & $n=31$ & $n=29$ & $n=27$ \\
& 0.75 & 0.64 & 0.59 & 0.44 & 0.48 & 0.75 & 0.31 \\
\hline
\end{tabular}

\footnotetext{
${ }^{1}$ average value; $(n)=$ number of live broiler chickens; no significant statistical differences were found in any case (student's t-test).
} 
Table 4. Effect of treated litter on feed utilization by broiler chickens

\begin{tabular}{ccccc}
\hline \hline Broiler age group & $\begin{array}{c}\text { Feed conversion: } \\
\text { body weight }\end{array}$ & $\begin{array}{c}\text { Feed conversion: } \\
\text { body weight gain }\end{array}$ & $\begin{array}{c}\text { Daily feed } \\
\text { intake }^{3}\end{array}$ & $\begin{array}{c}\text { Daily water } \\
\text { intake }^{4}\end{array}$ \\
\cline { 2 - 5 } Days 0-21 & 1.28 & 1.33 & - \\
Control & 1.26 & 1.31 & - \\
Treatments & 1.54 & 1.56 & 58.7 & 99.9 \\
Days 0-42 & 1.72 & 1.75 & 59.7 & 103.1 \\
Control & & & - \\
Treatments & & & & - \\
\hline
\end{tabular}

${ }^{1} \mathrm{~kg}$ feed/kg body weight; ${ }^{2} \mathrm{~kg}$ feed/kg body weight gain; ${ }^{3} \mathrm{~g} / \mathrm{kg}$ body weight;

${ }^{4} \mathrm{ml} / \mathrm{kg}$ body weight; ${ }^{3,4}$ the last day of broiler chicken rearing

The presented results show the high potential of starch granules enriched with carvacrol in controlling the lesser mealworm in poultry litter. The granules' high insecticidal activity and non-toxicity to poultry afford great possibilities for their practical application. The granules used in the study are cheap, easy to produce, environmentally friendly, easily biodegradable, and does not accumulate in the environment. It can be used, in contrast to synthetic insecticides, in a broiler house filled with birds. Furthermore, carvacrol has an anticoccidial action against Eimeria tenella and mixed Eimeria spp. infestation (Giannenas et al., 2003; OviedoRondon et al., 2006). The addition of terpenes to the litter for $A$. diaperinus control has been recommended by other researchers (Beier et al., 2014).

The last stage of our research will be to conduct trials under field conditions in a broiler house. Additionally, it is necessary to evaluate the amount of carvacrol in the tissues of birds, especially in the muscle tissue and the liver. However, based on other studies, it can be assumed that these granules can be used successfully without the risk of accumulation in tissues. Bioactive terpenes are quickly absorbed after oral, pulmonary, or dermal administration, and most are metabolized and either eliminated by the kidneys in the form of glucuronides or exhaled as $\mathrm{CO}_{2}$. Hence, their accumulation in the body is unlikely owing to the rapid clearance and short half-lives (Brenes and Roura, 2010). Essential oils or individual terpenes are widely recommended as a feed additive in poultry nutrition. Birds supplemented with the plant extracts showed higher body weight gain and increased feed consumption when compared with the other groups (Krishan and Narang, 2014). Carvacrol contained in the granules, through antibacterial and antiviral activities, will enhance the sanitary conditions of the chicken house. The application of starch granules enriched with carvacrol in broiler house would reduce the use of chemical insecticides and enable the production of healthy food.

\section{Conflict of Interests}

The authors declare no conflict of interest.

\section{Acknowledgments}

We thank Dr Roman Szymeczko, Associate Professor,
Faculty of Animal Breeding and Biology at the University of Technology and Life Science in Bydgoszcz (Poland) for supervising the research on poultry and MSc Joanna Błaszyk and Eng Martyna Zielińska for technical assistance. We are grateful to Professor Jarosław Kobak (Faculty of Biology and Environment Protection, Department of Invertebrate Zoology and Parasitology, Nicolaus Copernicus University, Torun, Poland) for help in statistical analysis.

\section{References}

Abbott WS. A method for computing the effectiveness of an insecticide. Journal of Economic Entomology, 18: 265-267. 1925.

Axtell RC and Arends JJ. Ecology and management of arthropod pests of poultry. Annual Review of Entomology, 35: 101-126. 1990.

Bajer K, Richert A, Bajer D and Korol J. Biodegradation of plastified starch obtained by corotation twin-screw extrusion. Polymer Engineering and Science, 52: 2537-2542. 2012.

Bajer K, Stasiek A and Bogucki M. Plastified starch processing by twin-screw extrusion. Przetwórstwo Tworzyw/Polymer Processing, 17: 265-271. 2011.

Bajer K, Raszkowska-Kaczor A and Szczepanik M. Sposób wytwarzania biodegradowalnego nośnika o właściwościach insektycydalnych w stosunku do Alphitobius diaperinus Panzer. Polish Patent Application - Number P. 422293. 2017.

Beier RC, Byrd 2nd JA, Kubena LF, Hume ME, McReynolds JL, Anderson RC and Nisbet DJ. Evaluation of linalool, a natural antimicrobial and insecticidal essential oil from basil: Effects on poultry. Poultry Science, 93: 267-272. 2014.

Brenes A and Roura E. Essential oils in poultry nutrition: Main effects and modes of action. Animal Feed and Science Technology, 158: 1-14. 2010.

Chernaki-Leffer AM, Sosa-Gómez DR, Almeida LM and Lopes Ivani de Oliveira Negrão. Susceptibility of Alphitobius diaperinus (Panzer) (Coleoptera, Tenebrionidae) to cypermethrin, dichlorvos and triflumuron in southern Brazil. Revista Brasileira de Entomologia, 55: 125-128. 2011.

Galdeano MC, Grossmann MVE, Mali S, Bello-Perez LA, Garcia MA and Zamudio-Flores PB. Effect of production process and plasticizers on stability of films and sheets of oat starch. Materials Science and Engineering C, 29: 492-498. 2009.

Giannenas I, Florou-Paneri P, Papazahariadou M, Christaki E and Botsoglou NA. Effect of dietary supplementation with oregano essential oil on performance of broilers after experimental 
infection with Eimeria tenella. Archiv für Tierernahrung, 57: 99-106. 2003.

Hazeleger WC, Bolder NM, Beumer RR and Jacobs-Reitsma WF. Darkling beetles (Alphitobius diaperinus) and their larvae as potential vectors for the transfer of Campylobacter jejuni and Salmonella enterica serovar Paratyphi B variant Java between successive broiler flocks. Applied and Environmental Microbiology, 74: 6887-6891. 2008.

Hickmann F, de Morais AF, Bronzatto ES, Giacomelli T, Guedes JVC and Bernardi O. Susceptibility of the lesser mealworm, Alphitobius diaperinus (Coleoptera: Tenebrionidae) from broiler farms of southern Brazil to insecticides. Journal of Economic Entomology, 111: 980-985. 2018.

Hippenstiel F, Abdel-Wareth AAA, Kehraus S and Südekum KH. Effects of selected herbs and essential oils, and their active components on feed intake and performance of broilers - a review. Archiv für Geflügelkunde, 75: 226-234. 2011.

Kapuśniak J, Jochym K, Bajer K and Bajer D. Review of chemical starch modification. Przemysł Chemiczny, 8: 1521-1526. 2011.

Krishan $\mathrm{G}$ and Narang A. Use of essential oils in poultry nutrition: A new approach. Journal of Advanced Veterinary and Animal Research, 1: 156-162. 2014.

Mitrus M. TPS and its nature. In: Thermoplastic starch. (Janssen L, Mościcki L. eds.) Vol. 84. Viley-VCH Verlag GmbH\&Co. KGaA. 2009.

Mitrus M and Mościcki L. Extrusion-cooking of TPS. In: Thermoplastic starch. (Janssen L, Mościcki L. eds.) Vol. 84. pp. 166167. Wiley-VCH Verlag GmbH\&Co. KGaA. 2009.

Mościcki L, Mitrus M and Oniszczuk T. Plastified starch processing. Tworzywa Sztuczne i Chemia, 6: 16. 2009.

Oviedo-Rondon EO, Hume ME, Hernández C and ClementeHernández S. Intestinal microbial ecology of broilers vaccinated and challenged with mixed Eimeria species, and supplemented with essential oil blends. Poultry Science, 85: 854860. 2006.

Park HR, Chough SH, Yun YH and Yoon SD. Properties of starch/ PVA blend films containing citric acid as additive. Journal of Polymers and the Environment, 13: 375-382. 2005.

Poutanen K and Forssell P. Modification of starch properties with plasticizer. TRIP 4-4, 128-132. 1996.

Prado GP, Stefani L, da Silva AS, Smaniotto LF, Garcia FRM and Moura NF. Alphitobius diaperinus (Coleoptera: Tenebrionidae) Susceptibility to Cunila angustifolia essential oil. Journal of Medical Entomology, 50: 1040-1045. 2013.

Raquez JM, Nabar Y, Srinivasan M, Shin BY, Narayan R and Dubois P. Maleated thermoplastic starch by reactive extrusion. Carbohydrate Polymers, 74: 159-169. 2008.

Roche AJ, Cox NA, Richardson LJ, Buhr RJ, Cason JA, Fairchild BD and Hinkle NC. Transmission of Salmonella to broilers by contaminated larval and adult lesser mealworm, Alphitobius diaperinus (Coleoptera: Tenebrionidae). Poultry Science, 88: 44-48. 2009.

Ross Broiler Management Handbook. Web. www.aviagen.com. 2014. Accesed on June 11, 2018

Rychter P, Kota M, Bajer K, Rogacza D, Sisková A and Kapuśniak J. Carbohydrate Polymers, 137: 127-138. 2016.
Salin CY, Delettre R, Cannavacciuolo M and Vernon P. Spatial distribution of Alphitobius diaperinus (Panzer) (Coleoptera: Tenebrionidae) in the soil of a poultry house along breeding cycle. European Journal of Soil Biology, 36: 107-115. 2000.

Spychaj T, Spychaj S and Wilpiszewska K. Sposób otrzymywania termoplastycznych hydrofobowych polimerów skrobiowych i produktów stosowanych do otrzymywania termoplastycznych hydrofobowych polimerów skrobiowych. Polish Patent No. PL 203055/ B1. 2006.

Szczepanik M and Szumny A. Insecticidal activity of star anise (Illicum verum Hook. F.) fruits extracts against lesser mealworm, Alphitobius diaperinus Panzer (Coleoptera: Tenebrionidae). Allelopathy Journal, 27: 277-288. 2011.

Szczepanik M, Zawitowska B and Szumny A. Insecticidal activities of Thymus vulgaris essential oil and its components thymol and carvacrol against larvae of the lesser mealworm, Alphitobius diaperinus Panzer (Coleoptera: Tenebrionidae). Allelopathy Journal, 30: 129-142. 2012.

Szczepanik M, Walczak M, Zawitowska B, Michalska-Sionkowska M, Szumny A, Wawrzeńczyk C and Swiontek-Brzezinska M. Chemical composition, antimicrobial activity and insecticidal activity against the lesser mealworm Alphitobius diaperinus (Panzer) (Coleoptera: Tenebrionidae) of Origanum vulgare L. ssp. hirtum (Link) and Artemisia dracunculus L. essential oils. Journal of Science of Food Agriculture, 98: 767-774. 2018.

Szołyga B, Gniłka R, Szczepanik M and Szumny A. Chemical composition and insecticidal activity of Thuja occidentalis and Tanacetum vulgare essential oils against larvae of the lesser mealworm, Alphitobius diaperinus. Entomologia Experimentalis et Applicata, 151: 1-10. 2014.

Testa M, Segat JC, Baggio RA, Galli GM, Barreta CRDM, Mendes RE, da Silva AS and Baretta D. Cinnamonum zeylanicum essential oil reduced infestation by Alphitobius diaperinus in poultry litter. Acta Scientiae Veterinariae, 46: 1532. 2018.

Thunwall M, Kuthanová V, Boldizar A and Rigdahl M. Film blowing of thermoplastic starch. Carbohydrate Polymers, 71: 583-590. 2008.

Tomberlin JK, Richmand D and Myers HM. Susceptibility of $\mathrm{Al}$ phitobius diaperinus (Coleoptera: Tenebrionidae) from broiler facilities in Texas to four insecticides. Journal of Economic Entomology, 101: 480-483. 2008.

Van Soest JJG and Knooren N. Influence of glicerol and water content on the structure and properties of extruded starch plastic sheets during aging. Journal of Applied Polymer Science, 64: 1411-1422. 1997.

Vaughan JA, Turner EC and Ruszler PL. Infestation and damage of poultry house insulation by the lesser mealworm, Alphitobius diaperinus (Panzer). Poultry Science, 63: 1094-1100. 1984.

Watson DW, Guy JS and Stringham SM. Limited transmission of turkey Coronavirus in young turkeys by adult Alphitobius diaperinus (Coleoptera: Tenebrionidae). Journal of Medical Entomology, 37: 480-483. 2000.

Yu J, Chen S, Gao J, Zheng H, Zhang J and Lin T. A study on the properties of starch/glycerine blend. Starch/Stärke, 50: 246250. 1998. 